\section{Japan faces opposition over plan to raise tuition fees}

Tokyo. Japan's science community is expressing concern about a proposal to increase tuition fees for students studying science, engineering and medicine at Japan's national universities.

All undergraduates at the 98 national universities at present pay the same tuition fees, whatever their discipline. From 1998, however, students in science, engineering and medical departments may have to pay higher fees than other students, following a proposal by the Ministry of Finance aimed at improving Japan's deteriorating public finances.

Senior scientists and academics are concerned about the long-term impact on Japan's science and technology base. They argue that the role of national universities is to foster scholarship equally in all core disciplines. "It is a very bad policy" and shows that the ministry "does not understand the meaning of education", says Hiroyuki Yoshikawa, president of the University of Tokyo.

$\mathrm{He}$ and other academics argue that the proposal will impede the transfer of knowledge to the next generation and send out the wrong message to society about the importance of science and technology. Critics also argue that raising tuition fees will discourage students from taking science, engineering and medical degrees.

"We need to educate more students in of National Universities. find another solution," he says. 1998 are not available. humanities. science and technology and this proposal is not healthy for Japan's future," says Akito Arima, president of the Institute of Physical and Chemical Research. The policy is also strongly opposed by the Japan Association

The education ministry has successfully resisted similar proposals in the past to increase tuition fees. But this time pressure from the finance ministry for the proposal to be accepted has mounted in the wake of this year's expensive bail-out by the Japanese government of failed housing loan companies, and increased costs involved in providing science, engineering and medical curricula at national universities. "The pressure is much higher" than previously, says Arima. "I hope that they can

Annual tuition fees at national universities are scheduled to rise next year by almost 5 per cent from $¥ 447,600$ to $¥ 469,200$ (US\$3,970 to $\$ 4,160$ ). Figures for the proposed extra fees that science, engineering and medical students may face from

Students at private universities in Japan, which number more than 400 , already pay about 20 per cent more for science and engineering courses and more than 500 per cent more for medical and dental courses, compared with the liberal arts and

Richard Nathan

\section{. . . as research funds take off again}

Tokyo. Japan spent a record $¥ \mathbf{1 4 , 4 0 8}$ billion (US\$129 billion) on scientific research and development in 1995, an increase of 6 per cent on the previous year, according to a survey of 15,700 organizations by the Management and Coordination Agency, which is affiliated to the prime minister's office.

The increase - the first for three years - was mainly due to improved economic conditions and two supplementary budgets from the Japanese government in 1995 . The budgets contained substantial subsidies for research, designed to boost Japan's recession-hit economy, according to government officials.

Last year, Japanese universities, private and public research institutes, and companies spent the equivalent of 2.96 per cent of gross domestic product on scientific research - more than any other industrialized nation. Research spending at universities increased by 8.3 per cent and spending at research institutes by 9 per cent.

\section{Australian universities brace for higher fees after Senate vote}

Sydney. Scientists have failed in their campaign to reverse the Australian government's decision to increase student fees for university courses. The finely balanced Senate rejected Opposition moves to oppose the increases, which were announced in the budget in August. Two independent senators backed the Coalition government, ensuring passage of the legislation.

Science-based courses are among the hardest hit, with a rise in fees of 92 per cent to $\mathrm{A} \$ 4,700$ (US\$3,760) a year. Medicine, dentistry, veterinary science and law will suffer a rise of 125 per cent to $A \$ 5,500$. Under the Higher Education Contribution Scheme, graduates will have to pay the fees after leaving university when their taxable income reaches $A \$ 20,700$ a year. Until now the threshold has been $\mathrm{A} \$ 28,000$.

Amanda Vanstone, the education minister, introduced the increases partly to make up for a 5 per cent cut in operating grants for universities (see Nature 382, 569; 1996).

University enrolments for the coming academic year have fluctuated between universities and states. Older institutions report only minor effects from the fee increases, while newer institutions are suffering drops in the number of entrants, especially for science-based courses.

The contrast is shown by comments by the vice-chancellors of the relatively new Victoria University of Technology and the older University of Sydney. A “despondent” Jarlath Ronayne at Victoria says his university has had up to 38 per cent fewer first-preference applications in science. He predicts that Australia will have to 'import' scientists - "disastrous for the future of the country".

But Gavin Brown at Sydney says science applications are 4 per cent higher. $\mathrm{He}$ is "relieved" that the legislation has been passed. So too is Stuart Hamilton, the new chief executive of the Australian Vice-Chancellors' Committee, most members of which had reluctantly urged the Senate to approve the measures in the interests of retaining some stability in the university system.

Vanstone describes the political victory as "a vote of confidence in Australian universities". Meanwhile, all universities are undergoing painful restructuring, with faculties, departments, courses and campuses amalgamating and shrinking as administrators come to terms with lower public funding.

Another controversial measure, approved by the Senate, allows universities from 1998 to enrol up to a quarter of their entrants from among Australian residents who can pay fees for the full cost of their courses. Universities were previously allowed to charge full fees only to students from overseas. 